\title{
A REVISION OF THE CHYTONIX PERSSONI BERIO, 1973 SPECIES COMPLEX (LEPIDOPTERA, NOCTUIDAE, CONDICINAE) WITH AN ANNOTATED LIST OF EURASIATIC TAXA
}

\author{
SÁNDOR Tibor KovÁcs ${ }^{1}$ and LÁsZló RonKAY² \\ ${ }^{1}$ H-6724 Szeged, Kossuth Lajos sgrt 43, Hungary; E-mail: kovsoni1939@citromail.hu \\ ${ }^{2}$ Department of Zoology, Hungarian Natural History Museum \\ H-1088 Budapest, Baross u. 13, Hungary; E-mail:ronkay.laszlo@nhmus.hu
}

The Chytonix perssoni species-complex is revised, the two main lineages are characterised and three new species, C. nemperssoni, C. viridifusa, and C. tobiasmalmi spp. n. are described. 29 figures illustrate the imagoes and male and female genitalia. An annotated list of the Eurasiatic taxa is provided.

Key words: Noctuidae, Condicinae, Chytonix, new species, annotated list of Eurasiatic species

\section{INTRODUCTION}

The genus Chytonix Grote, 1874 is one of the large Holarctic genera which was never revised. The taxonomic status and correct generic placement of certain taxa belonging to Chytonix sensu lato (including the taxa associated with Paroligia Warren, 1913) were clarified (e.g. Speidel 1992, Lafontaine \& Sснміdт 2010, etc.), but the real diversity of the genus (see e.g. Poole 1989) and the composition of local faunas is rather obscure in the most recent catalogues (Heppner \& Inoue 1992, Chen 1999, Kononenko \& Pinratana 2013, etc.). The exceptions are the catalogues dealing with the fauna of the northernmost part of the range of Chytonix like Japan, Korea, or the Russian Far East where only a limited number of species occur (see Sugi (in Inoue et al.) 1982, Kononenko et al. 1998, Behounek 2002, Kononenko 2005, Kononenko \& Han 2007).

The genus is externally rather polymorphic including numerous, externally sometimes remarkably differently looking species. Certain lineages resemble large species of the Bryophilinae genera Oederemia Hampson, 1908 or Victrix Staudinger, 1871, others can be confused with the Oligia Hübner, 1821 generic complex, some groups of the wide sense Athetis Hübner, 1821, or even the subfamily Eustrotiinae. Moreover, there are species which are incorrectly associated with different genera, for instance, e.g. circulorum Berio, 1973 which was originally described as Perigea, subsequently placed into the genera Condica or Platysenta but belongs, in reality, into Chytonix.

This situation provides a rather high uncertainty in the delimitation of the genus Chytonix and the compilation of its taxonomic content. It is worth to note that the south-eastern Palaearctic and Oriental species of the above- 
mentioned large groups which may contain externally similar species are also never revised after the Hampsonian age and the Seitz series. Thus, there could be a number of poorly known species which are actually misplaced (or simply overlooked) and never associated with Chytonix or Paroligia Warren, 1913.

Our basic aim is to clarify this situation, define the borders of the genus Chytonix and revise its taxonomic content. The present paper is the first step in this work, containing the revision of the Chytonix perssoni species complex. It was known by a single species but the thorough investigation of the types and the recently collected material from the southern Himalayas and northern Indochina proved a much larger diversity of the clade; even the type-series of C. perssoni Berio, 1973 contains two externally very similar but by the genitalia strikingly different species. The wide sense perssoni-group includes in fact two distinct and clearly separable species-groups the characterisation of which and the descriptions of the new taxa are given below, as well as a provisoric checklist of the eastern and south-eastern Asiatic species of Chytonix (s.l.).

\section{MATERIAL AND METHODS}

The material examined belongs to the Hungarian and the Swedish Natural History Museums and certain large private collections (see below).

The genitalia slides were prepared by the standard methods, macerating after treatment with ca $10 \% \mathrm{KOH}$, cleaning in concentrated lactic acid and dehydrating in concentrated ethanol. The copulatory organs were stained with eosine and embedded in Euparal.

The habitus of the specimens was photographed with a Nikon D90 camera; the images of the genitalia slides were taken by a Nikon Eclipse 80i photomicroscope with Nikon DS-Fi2 digital camera. The images are archived in the photo catalogue of the Heterocera Ltd, Budapest.

Abbreviations: GB - genitalia slide of Gottfried Behounek; GYP - genitalia slide of Péter Gyulai; HNHM - Hungarian Natural History Museum, Budapest; KST - genitalia slide of Sándor T. Kovács; NHRS-TOBI - registry number of Tobias Malm in the collection of the Naturhistoriska Riksmuseet (Royal Natural History Museum), Stockholm; NRM Stockholm - Naturhistoriska Riksmuseet (Royal Natural History Museum); RL - genitalia slide of László Ronkay.

\section{SYSTEMATIC PART}

This preliminary checklist of the genus Chytonix (s.l.) presented below is still just an illustration of the facts mentioned in the Introduction. It can be easily seen how large is the variation of the original combinations, belonging to different subfamilies distinguished during the time of publication. It is worth a note that as the genus was established for a Nearctic group of species (the palliatricula-group), it was rather slowly incorporated into the knowledge on the Palaearctic fauna even if the majority of the species of the wide sense Chytonix are distributed along the Pacific Coast and in the monsoonic eastern and 
south-eastern parts of Asia. These species were originally associated with various genera often belonging to different subfamilies of Noctuidae (e.g. Bryophila, Trachea, Oligia, Erastria, Selepa, etc.) and were subsequently transferred into Chytonix (s.l.), generally without thorough comparisons. A revision of the Eurasiatic Chytonix (s.l.) taxa would be highly desirable; this revision will supposedly result in radical changes in their proper generic placement. The target group of the present paper, the C. perssoni clade, belongs, according to our studies, to Chytonix s. str., displaying the closest relationships with the palliatricula-group.

The taxa included in the checklist were not revised recently, though certain combinations (e.g. C. circulorum, C. nigrithorax) are first published here and several taxa belonging to other genera (see e.g. SpEIDEL 1992) are omitted from the lists provided by Poole (1995) under the genera Chytonix and Paroligia. It must be noted that a number of recently published papers/books and websites dealing with the fauna of regions or countries or simply listing the species of Chytonix harbour several mistakes, even if the correct taxonomic placement of the given taxa are clarified and published.

There are a number of names which could refer to the same species (e.g. albiplaga and niveiplaga, clethria and variegata, nigrithorax and intermixta, etc.), while it is quite clear that some of the names cover more than one species (e.g. umbrifera, perssoni, etc.). There are a few di- or polymorphic species (e.g. pallidisca, variegata, etc.) the different colour forms of which were described in many publications and are usually correctly synonymised (see e.g. Poole 1989, Sugi in Heppner \& Inoue 1992, Speidel 1992, etc.). Finally, there are still supposedly several undescribed species, mostly from the Himalayan-SinoPacific subregion (from Nepal, China, Indochina, Taiwan, etc.), three of them are described here, and others are targets of forthcoming papers.

\section{Genus Chytonix Grote, 1874}

Chytonix Grote, 1874, Bulletin of the Buffalo Society of Natural Sciences 2: 14, 66. Typespecies: Apamea iaspis Guenée, 1852, Histoire Naturelle des Insectes. Species General des Lepidoptères 5: 209, by original designation. The type-species is synonymous with Bryophila palliatricula Guenée, 1852, Histoire Naturelle des Insectes. Species General des Lepidoptères 5: 26.

List of the recognised Eurasiatic taxa (in alphabetic order; with the original combinations and the type-locality in brackets)

adusta Draudt, 1950 (China) albiorbis (Moore, 1882) (Erastria; India, syn. of pallidisca Moore, 1881) albiplaga Hampson, 1914 (Taiwan; subsequent (incorrect) combination: Chytonidia albiplaga) 
albipuncta (Hampson, 1894) (Bryophila; Sikkim; subsequent (incorrect)

combination: Chytonidia albipuncta)

albiquadrata Draudt, 1950 (China)

albonotata (Staudinger, 1892) (Bryophila; Ussuri region)

circulorum (Berio, 1973) (Perigea; Burma)

clethria Wileman \& West, 1929 (Taiwan)

conjuncta (Wileman, 1914) (Trachea; Taiwan)

conjuncta bipectinata (Berio, 1977) (continental China)

costimacula Wileman, 1915 (Taiwan)

diehli Behounek, 2002 (Sumatra)

excurvata (Hampson, 1898) (Bryophila; Sikkim)

fusca (Moore, 1882) (Erastria, syn. of pallidisca Moore, 1881;

glaucescens (Butler, 1889) (Daxata; India, syn. of vermiculata)

glaucostigma (Hampson, 1894) (Bryophila, Burma)

hastata (Moore, 1882) (Hadena; Darjeeling)

imitans Draudt, 1950 (China, Atuntse)

intermixta (Leech, 1900) (Apamea, China: Atuntse)

khasiana (Hampson, 1894) (Bryophila, Khasis)

mediofasciata (Draudt, 1950) (Oligia; China, West-Tienmushan)

melanoleuca Wileman, 1915 (Taiwan)

minima Draudt, 1950 (China)

nadgani (Hampson, 1891) (Selepa, India)

nanata Draudt, 1950 (= minima Draudt)

nemperssoni sp. n. (Northern Vietnam)

nigribasalis Hampson, 1908 (China; syn. of albonotata)

nigrithorax (Draudt, 1950) (Oligia, China)

niveiplaga (Draudt, 1950) (Oligia, China: Linping)

nubila (Moore, 1882) (Paroligia, syn. of pallidisca, Darjeeling)

obliquifascia (Hampson, 1894) (Bryophila; Bhutan, syn. of pallidisca)

olethria Wileman \& West (Japan; syn. of albonotata)

pallidisca (Moore, 1881) (Erastria; Darjeeling)

perssoni Berio, 1973 (Burma)

ptyophora (Hampson, 1908) (Oligia; India, Himachal Pradesh)

subalbonotata Sugi, 1959 (Japan)

sumatrana Behounek, 2002 (Sumatra)

tobiasmalmi sp. n. (Nepal)

umbrifera (Butler, 1889) (Hyboma, India, Dharmsala)

undara (Swinhoe, 1890) (Anophia, syn. of vermiculata)

variegata Wileman, 1914 (Taiwan)

vermiculata (Snellen, 1880) (Erastria; India)

viridifusa sp. n. (Northern Thailand) 


\section{CHARACTERISATION OF THE CHYTONIX PERSSONI SPECIES-COMPLEX}

The perssoni-clade belongs to Chytonix sensu stricto; its genitalia features show close relationships with the palliatricula-group which includes the typespecies. The perssoni-clade contains two distinct lineages (the perssoni- and the viridifusa-groups) which are easily separable by their external and genital features as well as their bionomics.

The diagnostic features of the perssoni-clade are the rather robust body, the shortened forewing shape, the appearance of the shortly pectinated male antenna and the characteristic structure of the genitalia, especially the males. The members of both species-groups are often confusingly similar externally, however, the genitalia show conspicuous differences in both sexes.

The two species of the perssoni-group (Figs 14-23) are somewhat smaller in size than those of the two species of the viridifusa-group (wingspan 28-30 $\mathrm{mm}$ and $31-33 \mathrm{~mm}$ ), having a slightly more slender body and a more rounded forewing apex with only shortly fasciculate male antenna. The forewings of the species of the perssoni-group are more vividly coloured and more contrastingly marked than those of the viridifusa-group, without metallic green scales and sheen.

The genitalia of the two externally very similar species show conspicuous specific differences and a series of features which distinguish the perssoniand the viridifusa-groups; these differences are summarised below.

In the male genitalia of the perssoni-group (Figs 1-6), the strongly sclerotised costal area and the variably shaped digitus is located in the medial third of the valva, the harpe is more or less pyramidal, the armature of the vesica is either reduced or composed of a larger number of cornuti covering the basal half of the vesica while the carinal plate is strongly spinose-serrate. In the female genitalia (Figs 10,11), the antrum of the two species is differently built however the posterior end of ductus bursae is wide and sclerotised.

The members of the perssoni-group are (at least) bivoltine, with early spring and summer generations; the moths are on the wing from February to June and from July to the end of August.

The two taxa of the viridifusa-group, C. viridifusa sp. n. and C. tobiasmalmi sp. n. (Figs 24-29), are larger in size, their body is much more robust, with very broad tegulae, the male antenna is finely, shortly bipectinate, and the forewing apex is pointed, with slightly concave outer margin below termen. The forewing markings are more obsolescent, finer grey or blackish defined, except the strongly angled lower section of the antemedial line; the forewings are often with fine mossy green suffusion.

In the male genitalia (Figs 7-9), the sclerotised costal area is extended far towards the cucullus and the cuneate or spine-like digitus is located close to 
the ventral edge of the cucullus; the harpe is much larger, flattened and more or less quadrangular with pointed dorsal process anteriorly. The carinal plate of aedeagus is generally smoothly sclerotised, ventrally prolonged and beakshaped, and the armature of the vesica consists of two large subbasal groups of long, spiniform cornuti.

The female genitalia (Figs 12,13) are characterised by the broadly calyculate postvaginal plate, the thin ostium bursae, the weakly sclerotised antrum, the short and narrowly tubular, membranous ductus bursae and the rugoseribbed, subconical or cask-shaped, partly sclerotised appendix bursae connected to the corpus bursae with variably broad, membranous anterior section.

The members of the viridifusa-group are univoltine late autumnal and winter species; the moths can be found from the end of October to the end of January.

\section{DESCRIPTION OF THE NEW TAXA}

\section{Chytonix perssoni Berio, 1973}

(Figs 1-3, 14, 16-18)

Chytonix perssoni Berio, 1973, Annali del Museo Civico di Storia Naturale Giacomo Doria 79: 144, fig. 49. Type-locality: Burma, Kambaiti. Holotype: male, in coll. NRM Stockholm.

Type material examined - Holotype male, Burma (Myanmar), Kambaiti, 7000 ft, leg. Malaise, slide No.: RL11891m, NHRS-TOBI 364 (coll. NRM Stockholm). The two examined paratypes of $C$. perssoni belong to $C$. nemperssoni $\mathbf{s p}$. $\mathbf{n}$. The fourth specimen dissected by Berio and the genitalia of which are illustrated in the original description, belongs also to C. nemperssoni.

Additional material examined - Vietnam. 1 male, Prov. Lao Cai, Fansipan Mts, Frontier Satellite Camp, 1690 m, 24-25.VIII.1998, leg. A. Kun, slide No.: RL7675m; 2 males, Prov. Lao Cai, Fansipan Mts, Frontier Satellite Camp, 2240 m, 18-22.VIII.1998, leg. A. Kun, slide Nos: KST454m, KST460m (coll. HNHM). Thailand. 7 males, 3 females, Prov. Chiang Mai, Mt. Doi Phahompok, 16 km NW of Fang, 2000 m, 6-7.VIII.1999, leg. T. Csővári \& L. Mikus, slide Nos: KST428m, KST454m, KST455m, KST456m, KST460m, KST461m, KST471m, KST472m, KST473m (males); 1 female, Prov. Chiang Mai, Mt. Doi Phahompok, 16 km NW of Fang, 2100 m, 15.VIII.1999, leg. T. Csővári \& L. Mikus, slide No.: RL11940f; 2 females, Prov. Chiang Mai Mt. Doi Phahompok, 16 km NW of Fang, 2000 m, 14.VIII.1999, leg. T. Csővári \& L. Mikus, slide Nos: KST469f, KST470f (coll. T. Csővári, G. Ronkay and HNHM). China. Sichuan. 1 male, Gongga Shan, 2200 m, 29 $41^{\prime}$ N, 101 $58^{\prime}$ E, 25.V.-8.VI.2001, slide No.: GB5773m (coll. Stumpf/Becher). Shaanxi. 1 male, Tsinling Mts, Fopin Mt., 33 $45^{\prime}$ N, 107³8’ E, 1900 m, 1-30.VI.2004, leg. V. Siniaev, slide No.: GYP4576m (coll. P. Gyulai).

Remarks - The type series of the species consists of 5 specimens (four males, one female). The series is, however, mixed, and the four paratypes are not conspecific with the holotype. Unfortunately, the holotype remained undissected until our revision and the genitalia figure published by Berio illustrates another species, C. nemperssoni sp. $\mathbf{n}$., which is described below. 


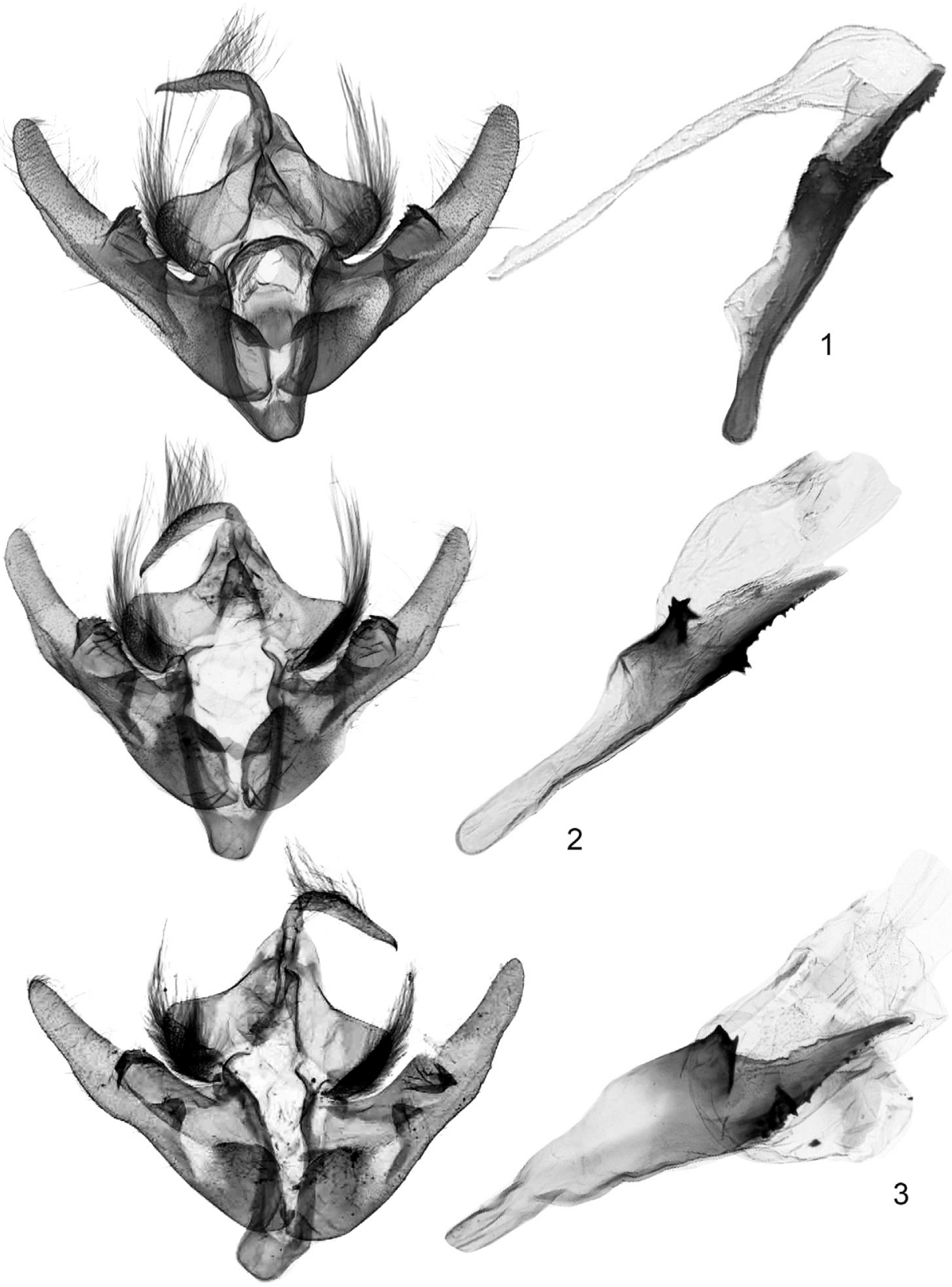

Figs 1-3. Chytonix perssoni Berio, male genitalia: 1 = holotype, Burma, slide No. RL11891m; 2 = North Thailand, slide No. KST428m; 3 = North Thailand, slide No. KST472m 
Diagnosis - Chytonix perssoni is confusingly similar to its sister species, $C$. nemperssoni sp. $\mathbf{n}$., the satisfactory identification requires the study of the genitalia. There are, however, certain features which may help in the preliminary separation of the two species by their external appearance. The forewings of C. perssoni are darker in colouration, with more extensive dark grey-brown or blackish-brown suffusion in the cell and the basal field, the entire wing is somewhat less shining and the subapical costal dark patch is large, more diffuse than in C. nemperssoni. Wingspan 28-30 $\mathrm{mm}$.

The genitalia of the two species are strikingly different in both sexes (see Figs 1-6). The male genitalia differ in practically all details while in the female genitalia the antrum and the ductus bursae have very different configuration and sclerotization.

The male clasping apparatus of $C$. perssoni (Figs 1-3) has, in comparison with $C$. nemperssoni (Figs 4-6), longer and thinner, medially less dilated uncus, considerably smaller and more rounded penicular lobes of tegumen, shorter and basally stronger, medially less curved valvae with much shorter apical section, reduced (often fully missing) coronal setae, broadly pyramidal harpe and very characteristic, strongly sclerotised and dorsally variably strongly serrate-crenellate (often cockscomb-like) digitus plate. The aedeagus of $C$. perssoni is distally much thicker than that of $C$. nemperssoni, with heavily sclerotised carinal processes: a very long, cuneate ventro-medial and two short, rather tooth- or thorn-like lateral extensions. The basal part of vesica is broad, inflated, more or less globular, distal part strongly tapering; the entire vesica is membranous, without cornuti.

In the female genitalia, C. perssoni (Fig. 10) can be distinguished from all other members of the species-group by the fine elliptical-rounded sclerotised ostial ring, the heavily sclerotised, obliquely funnel-like and on the internal surface densely scobinate-dentate antrum. The ductus bursae is remarkably shorter and less sclerotised than in C. nemperssoni (Fig. 11).

Distribution - The typical populations occur in northern Indochina (Burma, Thailand, and Vietnam). An externally somewhat different population is known in China (Shaanxi, Sichuan), however, the available material is insufficient for a detailed study.

\section{Chytonix nemperssoni sp. $\mathrm{n}$.}

(Figs 4-6, 11, 15, 19-23)

Holotype - Male, Vietnam, Prov. Lao Cai, Fan-si-pan Mts, Frontier Satellite Camp FTO, $22^{\circ} 16^{\prime} 86.6^{\prime \prime} \mathrm{N}, 103^{\circ} 16^{\prime} 81.7^{\prime \prime} \mathrm{E}, 1890$ m, 11-13.VIII.1998, leg. A. Kun; slide No.: KST453m (coll. HNHM).

Paratypes - Vietnam. 1 female, Prov. Lao Cai, Fansipan Mts, 1900 m, 14 km NW Sa $\mathrm{Pa}, 103^{\circ} 46,06^{\prime} \mathrm{E}, 2^{\circ} 20,9^{\prime} \mathrm{N}, 29-30 . V I I I .1998$, leg. A. Kun, slide No.: KST445f; 1 male, Prov. Lao Cai, Sa Pa district, Fansipan Mts, Frontier Satellite Camp, 22 $2^{\circ} 19^{\prime} 17.7^{\prime \prime} \mathrm{N}, 103^{\circ} 47^{\prime} 30.9^{\prime \prime} \mathrm{E}$, 
2240 m, 18-22.VIII.1998, leg. A. Kun, slide No.: KST390m; 1 male, Prov. Lao Cai, Sa Pa district, Fansipan Mts, Frontier Satellite Camp, 22 20'48,1"N N, 103 ${ }^{\circ} 47^{\prime} 45.2^{\prime \prime} \mathrm{E}, 1690$ m, 24-25. VIII.1998, leg. A. Kun, slide No.: KST573m (coll. HNHM). Burma [Myanmar]. 1 male, Kambaiti, 7000 feet, 11.IV.1934, leg. Malaise, slide No.: RL11892m, NRS-TOBI 1985; 1 female, Kambaiti, 7000 feet, 21.IV., leg. Malaise, slide No.: RL11893f, NRS-TOBI 1986 (paratypes of C. perssoni; coll. NRM Stockholm). Laos. 20 males, 5 females, Prov. Xiang Khouang, Phou Samsoun, $10 \mathrm{~km}$ E of Ban Peun, $2016 \mathrm{~m}, 1^{\circ} 8.717^{\prime} \mathrm{N}, 1^{\circ} 3^{\circ} 46.811^{\prime} \mathrm{E}, 15 . \mathrm{II} .2012$, leg. L. Peregovits \& A. Szappanos, coll. No. Lao2012PL_20, slide Nos: KST462, KST464 (males), KST467, KST468 (females); 2 males, 1 female; Prov. Xiang Khouang, Phou Samsoun, 11 km E of Ban Peun, $2030 \mathrm{~m}, 19^{\circ} 8.169^{\prime} \mathrm{N}, 103^{\circ} 47.122^{\prime} \mathrm{E}, 16 . \mathrm{II} .2012$, leg. L. Peregovits \& A. Szappanos, coll. No. Lao2012PL_21; 5 males, 2 females, Prov. Xiang Khouang, Phou Samsoun, 12 km E of Ban Peun, 2100 m, 19 ${ }^{\circ} 8.984^{\prime}$ N, 103 ${ }^{\circ} 47.484^{\prime}$ E, 17.II.2012, leg. L. Peregovits \& A. Szappanos, coll. No. Lao2012PL_22, slide Nos: KST463, KST465 (males), KST466 (female) (coll. L. Peregovits). Thailand. 1 male, Prov. Nan, 30 km E Pua, National Park, 1700 m, 14-15.IX.1999, leg. A. Szabó \& Z. Czere, slide No.: GB5773m (coll. G. Behounek).

Diagnosis - Chytonix nemperssoni is somewhat brighter in colouration than its sister species, C. perssoni. The forewings of the new species are slightly paler than those of $C$. perssoni, with fine dark irroration in the cell, the basal field is somewhat paler and the subapical costal dark patch is usually a finer, more blackish dot; otherwise the two species are very similar externally. The measures of the two species are identical, with the wingspan $28-30 \mathrm{~m}$.

The male genitalia of the new species (Figs 4-6) differ conspicuously from those of $C$. perssoni (Figs 1-3) in all mentionable parts of the clasping apparatus and the aedeagus with vesica. The uncus of $C$. nemperssoni is medially broadened, eagle-bill-like, the tegumen has large, broad and quadrangular penicular lobes. The valva is long and slender, distally curved, with a long cucullus covered densely with strong coronal setae. The harpe is small, narrow pyramidal, and the digitus is large, flattened and more or less quadrangular with a pointed dorsal process anteriorly.

The aedeagus of $C$. nemperssoni is slender, tubular with densely spinose surface of carina forming a spinose collar at distal end of aedeagus, ventral carinal bar strongly sclerotised and cuneate. The vesica is entirely tubular, tapering distally, basal third covered with medium-long and acute, spiniform cornuti.

The female genitalia of $C$. nemperssoni (Fig. 11) are characterised by the broad but short, rather membranous antrum and the sclerotised, flattenedtubular ductus bursae. The ostial ring is incomplete, appearing as a short ventral bar, and the postvaginal plate is weak, inconspicuous.

Chytonix perssoni, in comparison, has dark forewings, less contrasting irrorations in the cell, darker basal field, subapical patch obscured. The uncus is slenderer in its medial section; the tegumen does not have large, broad and quadrangular penicular lobes. The valva is shorter, wider, distally less curved, with a shorter cucullus, the harpe is broader pyramidal, and the digitus is large, with characteristic serrate-crenellate apical section. The aedeagus is distally thickened, the carina is heavily sclerotised, possessing a very long, 

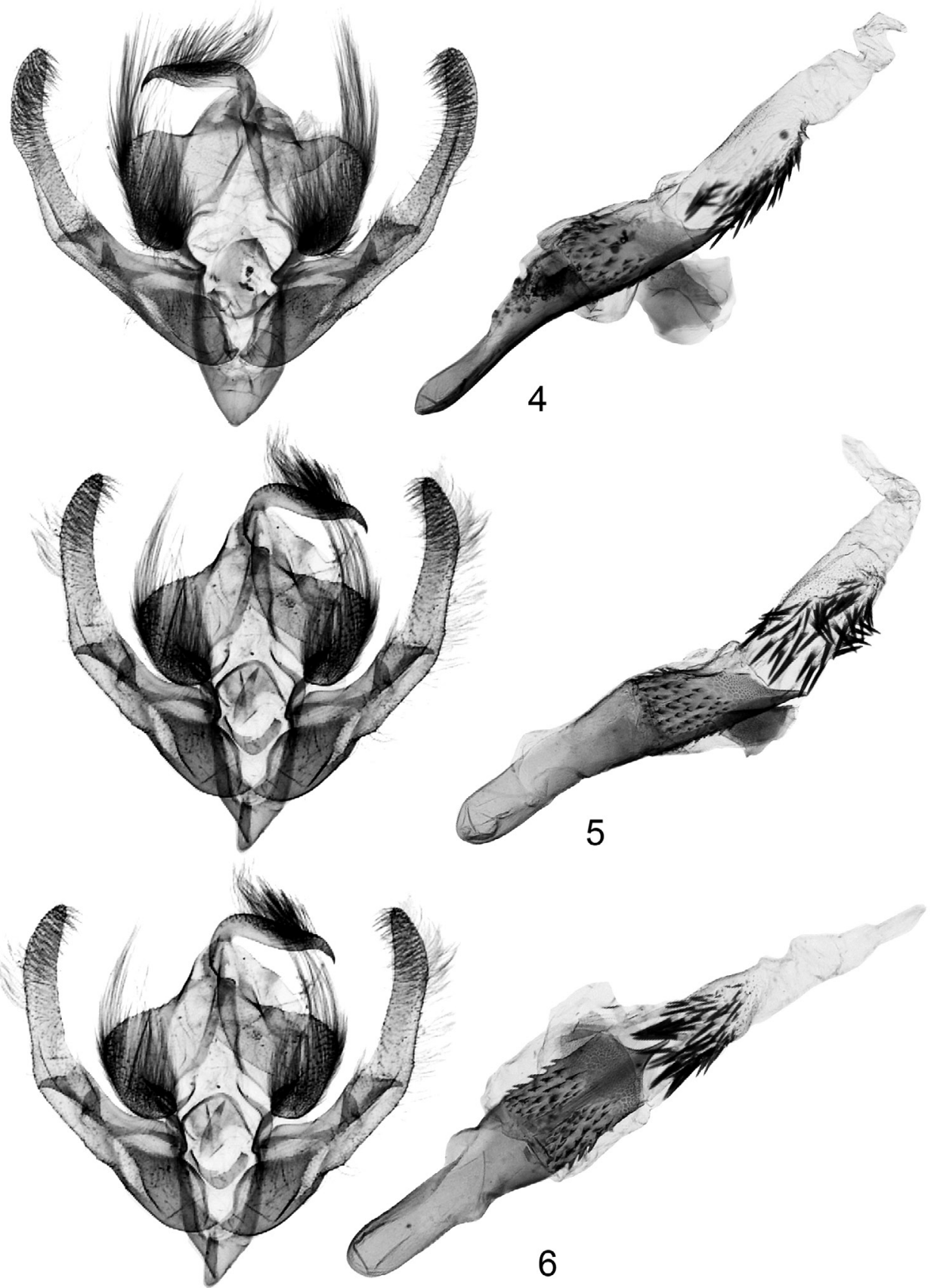

Figs 4-6. Chytonix nemperssoni sp. n., male genitalia: $4=$ holotype, North Vietnam, slide No. KST453m; 5 = paratype, Laos, slide No. KST464m; 6 = paratype, Laos, slide No. KST463m 
cuneate ventro-medial process and two short, rather tooth- or thorn-like lateral extensions. The vesica has broad, inflated, more or less globular basal section and strongly tapering distal part; the entire vesica is membranous, without cornuti. The female genitalia (Fig. 10) are characterised by the fine elliptical-rounded sclerotised ostial ring, the heavily sclerotised, obliquely funnel-like and on the internal surface densely scobinate-dentate antrum, and the relatively short and weakly sclerotised, partly scobinate ductus bursae.

Distribution - The new species is known from northern Indochina (Myanmar, Laos, Northern Thailand and Northern Vietnam). Chytonix nemperssoni inhabits the higher forest regions, between $1800-2300 \mathrm{~m}$ altitudes. The species is supposedly bivoltine; the adults of the spring generation are on the wing in February-April, the summer generation was found in August-September.

Etymology - The name "nemperssoni" is composed from the name of the sister-species of the new taxon ("perssoni") and the Hungarian word "nem" which means "not". Thus, the name of the new species means "not perssoni".

\section{Chytonix viridifusa sp. $\mathrm{n}$.}

(Figs 7-9, 12, 24-28)

Holotype - Male, Thailand, Prov. Chiang Mai, Mt. Phahompok, 2000 m, 20 km NW of Fang, 15.I.2004, leg. A. Szabó (coll. G. Ronkay).

Paratypes - Thailand. Prov. Chiang Mai. 5 males, with the same data as the holotype; 2 males, Mt. Phahompok, 2150 m, 20 km NW of Fang, 22-25.I.2004, leg. A. Szabó, slide No.: RL12301m; 3 males, 4 km SE Pang Faen, 1100 m, 31.I.2004, leg. A. Szabó, slide No.: RL11906m; 9 males, 1 female, Mt. Phahompok, 2150 m, 20 km NW of Fang, 28-29.I.2004, leg. A. Szabó, slide No.: RL11907f (coll. G. Ronkay); 1 male, Mt. Phahompok, 2007,847’N, 99643'E (sic), 2050 m, 13-17.I.2007, leg. T. Ihle, slide No.: GB5772m (coll. G. Behounek). Vietnam. 1 male, Prov. Lao Cai, Fansipan Mts, 10346.06'E, 22 $20.9^{\prime} \mathrm{N}, 1900-2000$ m, 2629.I.1999, leg. L. Peregovits, G. Ronkay \& L. Ronkay; slide No.: RL11905m (coll. G. Ronkay).

Diagnosis - The two closely related members of the species-group can be distinguished by certain external and genitalia features. Chytonix viridifusa has, in comparison with C. tobiasmalmi, uniformly greenish coloured collar and tegulae, greenish shaded forewing ground colour, basal area and lower part of median field darkened and the dark area extends towards postmedial line below cell. Antemedial line prominently angled above inner margin (below vein $\mathrm{A}_{1}$ ), postmedial line deeply angled below cell and somewhat curved outwards at inner margin; reniform stigma medially constricted, slightly 8-shaped. Wingspan 31-33 mm. Chytonix tobiasmalmi is darker in colouration, with less greenish scales in the vestiture of the head, the thorax and the forewing, the postmedial line is less sinuous, and the reniform stigma is more indistinctly encircled and less constricted at its apical third. 

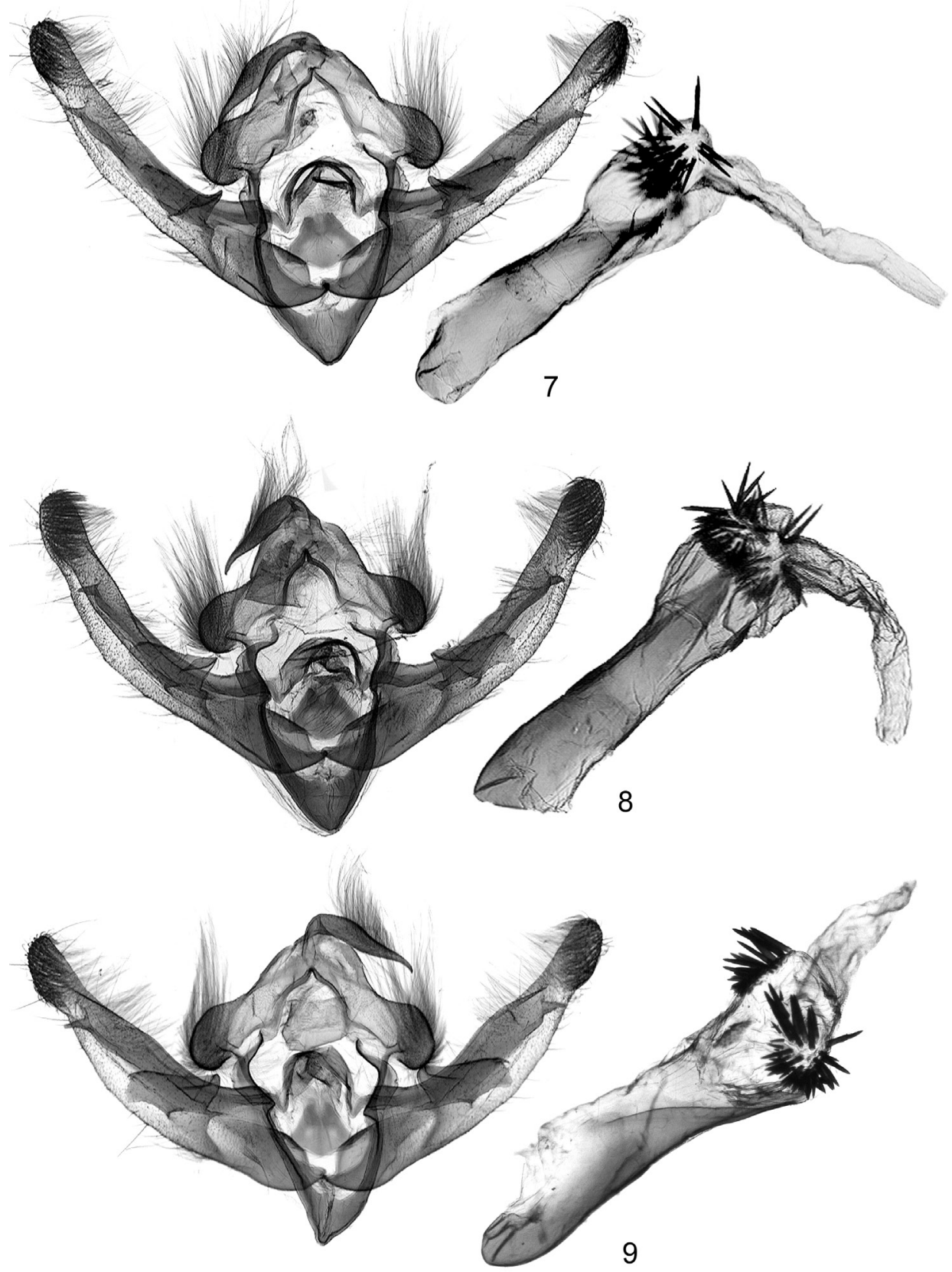

Figs 7-9. Chytonix viridifusa sp. n., male genitalia: 7 = paratype, Thailand, slide No. RL11906m; 8 = paratype, Thailand, slide No. RL12301m; 9 = paratype, Vietnam, slide No. RL11905m 
The male genitalia of C. viridifusa (Figs 7-9) are characterised in the general diagnosis of the $C$. perssoni species-group; no similar valval structure is known within the genus.

The specific features of the female genitalia of C. viridifusa (Fig. 12) are the very broad and almost evenly sclerotised postvaginal plate, the broadly $\mathrm{V}$ shaped ventral sclerotised bar of antrum, the short and narrow, weakly membranous ductus bursae, the subconical, proximally broadened, in most parts cristate-ribbed appendix bursae, and the large, elliptical-ovoid corpus bursae.

The female genitalia of Chytonix viridifusa are easily separable from those of C. tobiasmalmi (Fig. 13) by the larger postvaginal plate, the subconical, proximally broader, distally tapering appendix bursae and the larger, more elliptical corpus bursae. The postvaginal plate of $C$. tobiasmalmi is smaller and narrower, arcuate, the appendix bursae is broadened medially while the anterior and posterior sections are remarkably narrower, and the corpus bursae is smaller, discoidal-globular.

Distribution - The new species is known from Northern Thailand (Prov. Chiang Mai) and Northern Vietnam (Prov. Lao Cai). Most known specimens were collected at or above $2000 \mathrm{~m}$. a.s.l.; the moths are on the wing in January and are attracted strongly to light.

Etymology - The specific name refers to the fine mossy-green colouration of the vestiture of the head and thorax and the forewing; this feature is typical of this lineage and is more prominently expressed in this species than in its sister-species described below.

Remarks - The single known Vietnamese specimen of $C$. viridifusa differs from the typical Thai population by its paler, less greenish suffused forewings with more obscure lower angle of antemedial line above inner margin, less sinuous-laced postmedial line, being less angled inwards below cell.

The male genitalia of the Thai and Viet moths are very similar, though there are some differences in the shape of the valvae, the harpes and the juxta. It is not impossible that these two populations represent two distinct taxa but the material from Vietnam is insufficient for a more detailed comparison.

\section{Chytonix tobiasmalmi sp. n.}

(Figs 13, 29)

Holotype - Female, Nepal, Kanchenjunga Himal, Mechi, Taplejung area, Yamphudin village, $1800 \mathrm{~m}, 87^{\circ} 59^{\prime} \mathrm{E}, 27^{\circ} 28^{\prime} \mathrm{N}, 31 . X .1996$, leg. Gy. M. László \& G. Ronkay; slide No.: RL11908f (coll. G. Ronkay).

Diagnosis - The main external features of $C$. tobiasmalmi are matching with those of $C$. viridifusa, the main differences can be found in the intensity of the greenish shade in the pubescence of the head and thorax and the forewings 

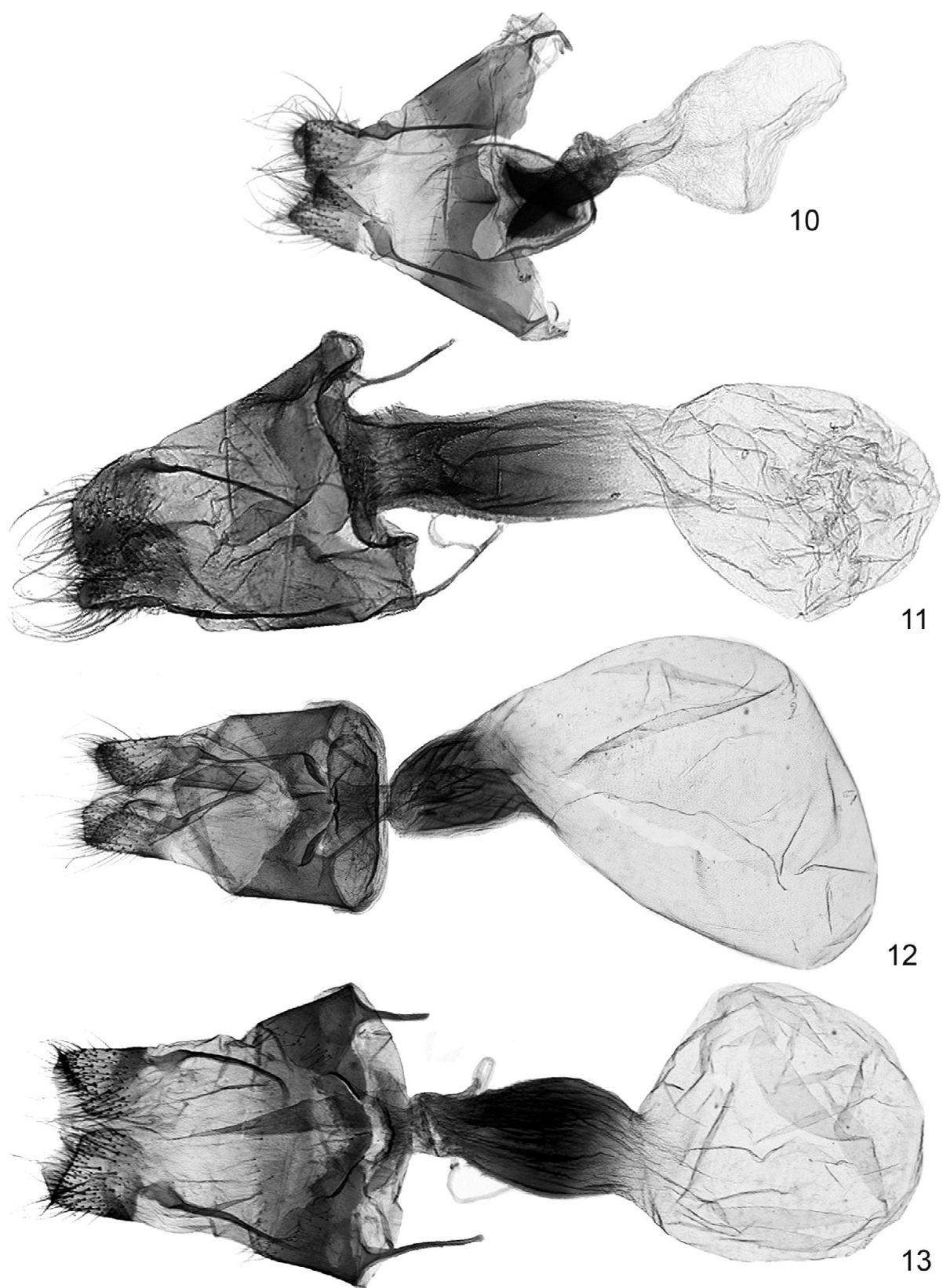

Figs 10-13. Chytonix spp., female genitalia: $10=$ C. perssoni Berio, North Thailand, slide No. RL11940f; $11=C$. nemperssoni sp. n., paratype, Laos, slide No. KST468f; $12=C$. viridifusa sp. n., paratype, North Thailand, slide No. RL11907f; $13=$ C. tobiasmalmi sp. n., holotype, Nepal, slide No. RL11908f 
and certain elements of the forewing pattern. Chytonix tobiasmalmi is darker in colouration than its sister-species (though the pale greenish colouration is clearly visible on the body and the forewings), the postmedial line is less sinu-
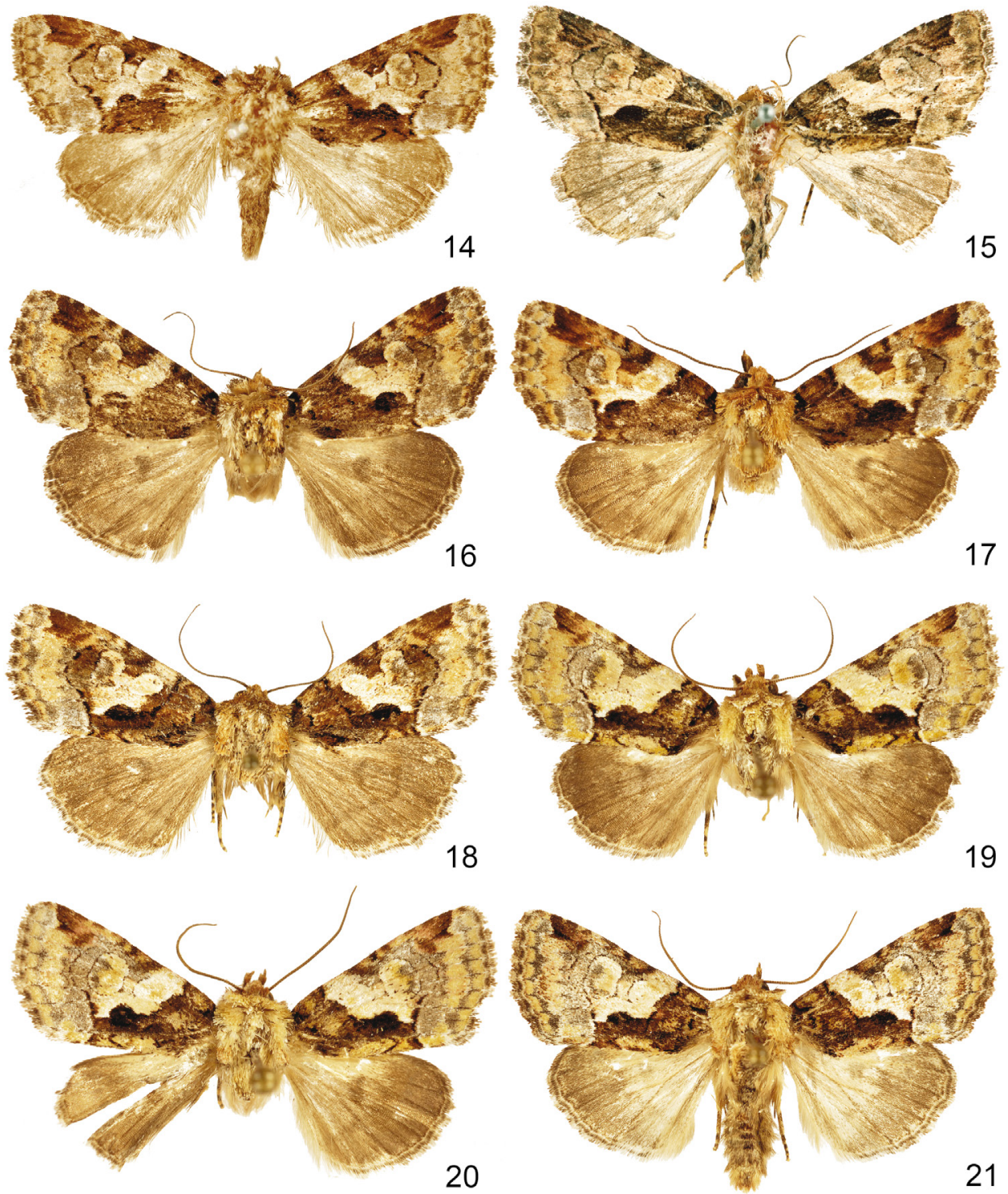

Figs 14-21. Chytonix spp.: $14=$ C. perssoni Berio, 1973, holotype, male, Burma; $15=$ C. nemperssoni sp. n., paratype, female, Burma (paratype of $C$. perssoni); $16-18=C$. perssoni Berio, 1973: $16=$ male, Thailand, $17=$ male, Vietnam, $18=$ female, Thailand; $19-21=C$. nemperssoni sp. n.: 19 = holotype, male, Vietnam, 20 = paratype, male, Vietnam, 21 = paratype, male, Laos 
ous and its lower section is perpendicular to inner margin, the stigmata are rather obsolescent, with poorly visible paler outlines, and the reniform stigma is broadly oval, only weakly constricted at apical third. Wingspan $32 \mathrm{~mm}$.
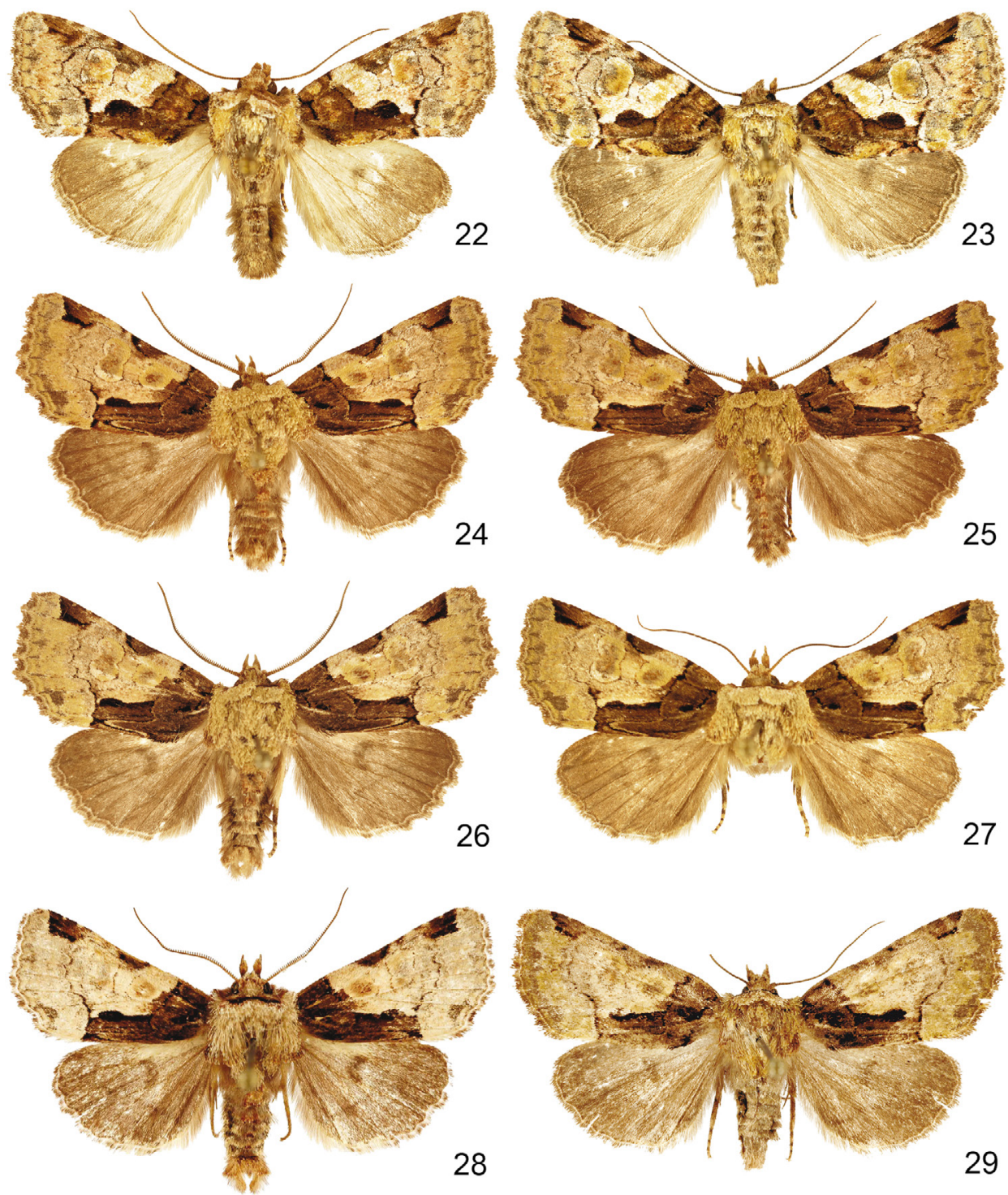

Figs 22-29. Chytonix spp.: $22-23=$ C. nemperssoni sp. n., paratype, Laos: $22=$ male, $23=$ female; $24-28=$ C. viridifusa sp. n.: $24=$ holotype, male, Thailand, $25-26=$ paratype, males, Thailand; $27=$ paratype, female, Thailand; $28=$ paratype, male, Vietnam; $29=C$. tobiasmalmi sp. n., holotype, male, Nepal 
The basic colouration of $C$. viridifusa is paler and more greenish-shaded, the postmedial line is generally more sinuous and its lower end is curved towards tornus at inner margin, and the reniform stigma is narrower, more distinctly outlined by fine dark line and paler annulus, and more constricted at its apical third.

The female genitalia of $C$. tobiasmalmi (Fig. 13) are characterised by the relatively small, finely arched postvaginal plate, the similarly shaped and sized ventral sclerotised bar or antrum, the longer and medially dilated, rather cask-shaped and in most parts cristate-ribbed appendix bursae connected with corpus bursae by narrower neck, and the discoidal-globular corpus bursae. In C. viridifusa (Fig. 12), the postvaginal plate is larger and more sclerotised than in C. tobiasmalmi, the ventral sclerotised plate of antrum is considerably smaller than the postvaginal plate, the appendix bursae is characteristically subconical, evenly tapering posteriorly and connected to corpus bursae at its broadest (anterior) part, and the corpus bursae is larger and more elongated than in its sister-species.

Etymology - The new species is dedicated to Dr Tobias Malm, Curator of the Lepidoptera Collection in the NRM Stockholm. His help was essential to clarify the taxonomic situation in the Chytonix perssoni species-group.

Distribution - Southern Himalayan. The only known specimen of the species was found relatively early, at the very end of October, in a rather low altitude region of the Kanchenjunga Himal in eastern Nepal.

Acknowledgements - The authors are indebted to Gottfried Behounek (Deisenhofen), Tibor Csővári (Budapest), Sabine Gaal-Haszler (Vienna), Péter Gyulai (Miskolc), Martin Lödl (Vienna), Tobias Malm (Stockholm), Wolfram Mey (Berlin), László Peregovits (Nagykovácsi), Gábor Ronkay (Budapest), Dieter Stüning (Bonn), Albert Szappanos (Kecskemét) and Alberto Zilli (London) for the access of their museum and private collections; and to Csenkey Lórántné (Budapest) for her technical assistance.

We are greatly appreciate to the two anonymous referees whose corrections, additions and advices helped very much in the improvement of the manuscript and led, hopefully, to the better harmonisation of the taxonomic papers published in Europe and in North America.

\section{REFERENCES}

Behounek, G. (2002): Studie der Gattung Chytonix Grote 1874 von Sumatra, mit Beschreibung von zwei neuen Arten (Lepidoptera, Noctuidae, Amphipyrinae). - Heterocera Sumatrana 12(3): 121-127.

Berio, E. (1973): Nuove species e generi di Noctuidae Africane e Asiatische e note sinonimiche. Part II. - Annali del Museo Civico di Storia Naturale Giacomo Doria 79: 126-171. 
Berio, E. (1977): Diagnosi di Noctuidae raccolte dal Dr. Höne dal Dr. Klapperich in Cina. Annali del Museo Civico di Storia Naturale Giacomo Doria 81: 221-245.

Chen, Y. X. (1999): Lepidoptera, Noctuidae. Fauna Sinica, Insecta 16. - Science Press, Beijing, 1596 pp.

Draudt, M. (1950): Beiträge zur Kenntnis der Agrotiden-Fauna Chinas. Aus den Ausbeuten Dr. H. Höne's (Beitrag zur Fauna Sinica). - Mitteilungen der Münchner Entomologischen Gesellschaft 40: 1-174, figs 1-37, plates I-XVIII.

Fibiger, M. \& Lafontaine, J. D. (2005): A systematic list of the Noctuoidea of Europe. - Esperiana 11: 93-205.

Grote, A. R. (1874): List of the Noctuidae of North America. - Bulletin of the Buffalo Society of Natural Sciences 2: 1-77, 1 plate.

Hampson, G. F. (1894): The Fauna of British India including Ceylon and Burma, Moths. Vol. 2. Taylor and Francis, London, 609 pp.

Hampson, G. F. (1908): Catalogue of the Lepidoptera Phalaenae in the British Museum. Vol. 7. Taylor and Francis, London, 709 pp, 16 plates.

Heppner, J. B. \& Inoue, H. (1992): Lepidoptera of Taiwan. Volume 1. Part 2: Checklist. - Scientific Publishers, Gainesville, 276 pp.

Kononenko, V.S. (2005): Noctuidae Sibiricae. Volume 1. An annotated check list of the Noctuidae (s.l.) (Insecta, Lepidoptera) of the Asian part of Russia and the Ural region. - Entomological Press, Sorø, 243 pp.

Kononenko, V.S. \& HAN, H. L. (2007): Atlas genitalia of the Noctuidae in Korea (Lepidoptera) In: PARK, K. T. (ed.): Insects of Korea [11]. - KNA \& CIS, Junghaeng-Sa, Seoul, 464 pp.

Kononenko, V. S. \& Pinratana, A. (2013): Moths of Thailand, Vol. 3, Part 2. Noctuoidea. An illustrated Catalogue of Erebidae, Nolidae, Euteliidae and Noctuidae (Insecta, Lepidoptera) in Thailand. - Brothers of St. Gabriel in Thailand, Bangkok, 625 pp.

Kononenko, V. S., Ahn, S. B. \& Ronkay, L. (1998): Illustrated catalogue of Noctuidae in Korea (Lepidoptera). - KRIBB \& CIS, Junghaeng-Sa, Seoul, Korea, 507 pp.

Lafontaine, J. D. \& Sснмidt, Сн. (2010): Annotated check list of the Noctuoidea (Insecta, Lepidoptera) of North America north of Mexico. - Zookeys 40: 1-239. https://doi. org/10.3897/zookeys.40.414

Poole, R. W. (1995): Noctuoidea: Noctuidae (part), Cuculliinae, Stiriinae, Psaphidinae (Part). In: Dominick, R. B. et al. (eds): The Moths of America North of Mexico, Fasc. 26.1. - The Wedge Entomological Research Foundation, Washington, 249 pp.

Speidel, W. (1992): New synonyms of Chinese noctuids (Lep., Noctuidae). - Esperiana 3: 9-15.

SugI, S. (1959): Descriptions of some new species of the Noctuidae (Lepidoptera). - Tinea 5(1): 286-292.

Sugi, S. (1982): Noctuidae (except Herminiinae). In: Inoue, H., Sugi, S., Kuroko, H., Moriuti, S. \& Kawabe, A. (eds): Moths of Japan 1: 669-913; 2: 334-405; plates 37, 164-223, 229, 278, 355-380. - Kodansha, Tokyo.

Sugi, S. (1992): Noctuidae (except Aganainae, Herminiinae and Nolinae). - In: Heppner, J. B. \& Inoue, H. (eds): Lepidoptera of Taiwan. 1(2): 171-202.

Wileman, A. E. (1914): New species of Arctiadae and Noctuidae from Formosa. - Entomologist 47: 161-169. https://doi.org/10.5962/bhl.part.15124

Wileman, A. E. (1915): New species of Noctuidae from Formosa. - Entomologist 48: 143147, 159-164, 191-196, 235-239.

Wileman, A. E. \& West, R. J. (1929): Descriptions of new species of Noctuidae. - Novitates Zoologicae 35: 1-27. https://doi.org/10.5962/bhl.part.10813

Received October 30, 2017, accepted January 15, 2018, published May 31, 2018 